\author{
P.I. Kolkovskyi, B.K. Ostafiychuk, M.I. Kolkovskyi, N.Ya. Ivanichok,
} S-V.S. Sklepova, B.I. Rachiy

\title{
Mechanisms of Charge Accumulation in Electrochemical Systems Formed Based on of Nanoporous Carbon and Manganese Oxide
}

\author{
Vasyl Stefanyk Precarpathian National University, Ivano-Frankivsk, Ukraine, Pkolkovskyy@gmail.com
}

\begin{abstract}
In this work, the processes occurring in electrochemical systems based on nanoporous carbon material and manganese oxide in an aqueous solution of lithium sulfate are analyzed. Furthermore, it is shows the feasibility of these materials combination cycling as electrodes of a hybrid electrochemical capacitor. The combination of electrode materials with different mechanisms of charge accumulation was determined. Consequently, an increase in the accumulated energy by more than $25 \%$ by the formation of an electric double layer and the occurrence of redox reactions based on carbon and manganese oxide respectively. The laboratory sample of an aqueous electrolyte hybrid electrochemical capacitor was formed. Moreover, the laboratory sample is electrochemically stable at an operating voltage of $2 \mathrm{~V}$.

Keywords: nanoporous carbon material, manganese oxide, hybrid electrochemical capacitors, lithium sulfate, voltammetry.
\end{abstract}

Received 11 November 2020; Accepted 15 December 2020.

\section{Introduction}

It is urgent task today the optimization of the methodology for the synthesis of electrode materials of highly efficient electrochemical charge storage devices. Typically, it is important that the new electrochemical devices should have high specific power and energy values, as well as operates for $>10^{6}$ charge/discharge cycles at a stable Coulomb efficiency.

Electrochemical capacitors (EC) is one of such devices in which charge is accumulated due to the occurrence of redox reactions and the formation of an electric double layer (EDL) at the interface of the electrode material with a large specific surface area $\left(1500-2000 \mathrm{~m}^{2} / \mathrm{g}\right)$ with electrolyte [1]. The particular attention is paid to the development of methods for the synthesis of new electrode materials that are not destroyed or degraded during the charge/discharge process [2, 3].

Activated carbon (AC) is one of the most common materials used to form classic EC electrodes. Moreover, supercapacitors were formatted based on AC, that operate on the charge / discharge principle of EDL [4].
On the one hand, the advantages of using AC are simple technique for production with high specific energy and energy characteristics, chemical and electrochemical stability, as well as the availability of raw materials and their low cost.

On the other hand, it is the insufficiently high accumulated specific energy of EC in comparison with power supplies prompts the development of a new type of electrochemical systems that can solve this problem. One of the ways to increase the specific energy is the formation of hybrid electrochemical capacitors (HECs), in which charge accumulation processes of different nature occur on paired electrodes [5], namely, a redox reaction and charge accumulation of a EDL on the one and other electrodes respectively. The use of a nonpolarized electrode raises the potential of a single element and increases the operating voltage of the EC, since in the equivalent circuit the second capacitor connected in series is removed, thereby increasing the amount of accumulated energy [6].

Thus, HECs attract considerable scientific and practical interest due to they provide high power, compared to batteries, accumulate more energy than 
conventional supercapacitors, and have a long cycle life [7]. Furthermore, it is possible that, HECs can be bridge the efficiency gap between the energy density of batteries and the high power density of conventional dielectric capacitors by implementing two different charge storage mechanisms, and thus provide rapid energy storage and release [8].

Typically, the material for a polarized electrode is an activated carbon material, and for an unpolarized one, it is promising to use oxides, hydroxides, and sulfides of transition metals.

In this work, we have been researched the porous structure of carbon material, the crystal structure of $\alpha-\mathrm{MnO}_{2}$ and the electrochemical characteristics of symmetric and hybrid electrochemical capacitors with electrodes based on the obtained materials in an aqueous electrolyte of lithium sulfate.

\section{Synthesis of materials and research methods}

Nanodispersed manganese oxide alpha form of predefined morphology was obtained by hydrothermal synthesis, in accordance with the redox reaction of $3 \mathrm{MnCl}_{2}+2 \mathrm{KMnO}_{4}+2 \mathrm{H}_{2} \mathrm{O} \rightarrow 5 \mathrm{MnO}_{2}+4 \mathrm{HCl}+2 \mathrm{KCl}$ [9].

The investigation of the phase composition and crystal structure of the obtained materials was carried out using X-ray diffractometric analysis on a DRON-3.0 diffractometer in the radiation of a copper anode $(\mathrm{Cu} \mathrm{K \alpha}-$ radiation).

The morphology of the obtained carbon materials was investigated by low-temperature porosimetry using a Quantachrome Autosorb Nova 2200e equipment. Before measurements, $\mathrm{AC}$ was degassed at $180^{\circ} \mathrm{C}$ for $18 \mathrm{~h}$. The specific surface area was determined using the BET $\left(\mathrm{S}_{\mathrm{BET}}\right)$ method with a linear dependence of

$1 /\left[\mathrm{W}\left(\mathrm{p}_{0} / \mathrm{p}\right)-1\right]$ on $\mathrm{p}_{0} / \mathrm{p}$ in the adsorption isotherm range for the $\mathrm{p}_{0} / \mathrm{p}$ ratio in the range from 0.05 to 0.35 . In addition, the Langmuir $\left(\mathrm{S}_{\mathrm{L}}\right)$ and DFT $\left(\mathrm{S}_{\mathrm{DFT}}\right)$ methods were used to determine the total surface area of microporous carbon materials. The area of micropores was determined by the $\mathrm{t}$-method $\left(\mathrm{S}_{\mathrm{t}-\mathrm{micro}}\right)$, and mesopores by the BJH method $\left(\mathrm{S}_{\mathrm{BJH}-m e s o}\right)$. The total pore volume $\left(\mathrm{V}_{\text {total }}\right)$ was calculated from the amount of adsorbed nitrogen at $\mathrm{P} / \mathrm{P}_{0} \sim 1.0$, the volume of micropores $\left(\mathrm{V}_{\text {micro }}\right)$ was determined using the $t$-method.

The research of the properties of electrochemical systems $\quad \alpha-\mathrm{MnO}_{2} /$ electrolyte, AC/electrolyte and AC/electrolyte/ $\alpha-\mathrm{MnO}_{2}$ was carried out in a threeelectrode cell using an Autolab PGSTAS/FRA-2 impedance spectrometer. The information on the electrochemical behavior of the $\alpha-\mathrm{MnO}_{2} /$ electrolyte system from 0 to $1 \mathrm{~V}$ potential window and the AC/electrolyte system in the range from -0.2 to $-1 \mathrm{~V}$ relative to the chlorine-silver reference electrode was obtained by cyclic voltammetry. The rate of the applied potential was varied in the range from 1 to $15 \mathrm{mV} / \mathrm{s}$. For comparison, the attached results of measuring the specific capacitance by the galvanostatic method at a constant current in the range from 0.1 to $15 \mathrm{~mA}$.

Working electrodes were prepared by applying a mixture of the material under research/acetylene black/polyvinylidene fluoride (solution in ethanol) on a nickel grid $(5 \mathrm{~mm} \times 5 \mathrm{~mm})$ in a mass ratio of 85 to 10 to 5 . The mass of the working electrode was $0.02 \mathrm{~g}$.

The research of the hybrid electrochemical capacitors behavior was carried out in a two electrode cell. The HECs electrodes were formed based on the same procedure. The formed electrodes were separated by a separator and placed in an electrochemical cell, which was hermetically sealed after filling with electrolyte.

\section{Results and Discussion}

According to the results of $\mathrm{X}$-ray analysis, a monophase ultrafine phase $\alpha-\mathrm{MnO}_{2}$ with a crystal structure of $\mathrm{Mn}^{4}+$ and $\mathrm{O}^{2-}$ was formed using the hydrothermal methods of synthesis at a temperature of $180^{\circ} \mathrm{C}$ for 48 hours, (JCPDSno.42-1348) (Fig. 1).

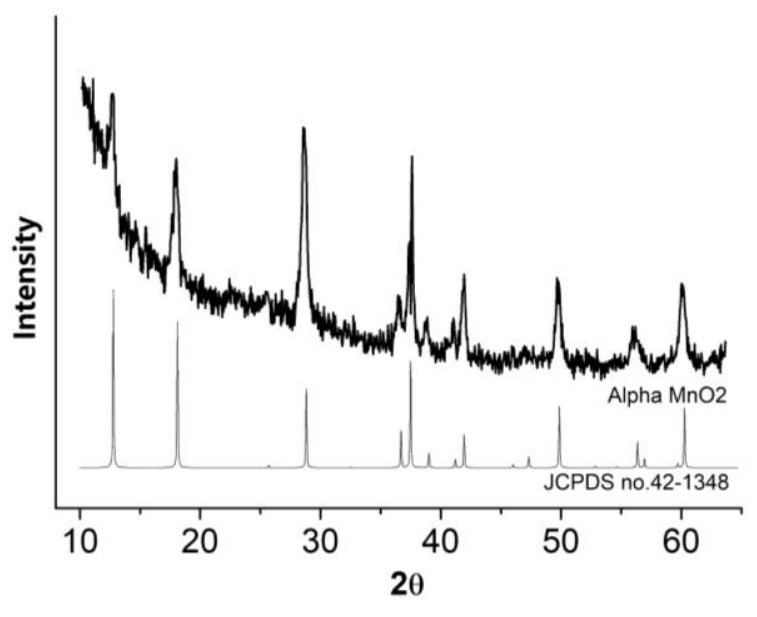

Fig. 1. XRD patterns of the obtained sample and reference (JCPDS no.42-1348) $\alpha-\mathrm{MnO}_{2}$ [9].

It was determined that, the average sizes of the coherent scattering regions are $12-16$ nanometers calculated by the Scherrer equation. Moreover, the four molar concentration of $\mathrm{KCl}$ ions is a key factor of the $\alpha-\mathrm{MnO}_{2}$ phase formation [9].

The adsorption/desorption isotherms obtained for AC are typical for microporous carbon materials was determined by low-temperature porosimetry [10]. The volume of sorbed nitrogen increases to $450 \mathrm{~cm}^{3} / \mathrm{g}$ with an increase in relative pressure to unity and gradually decreases during desorption, forming a hysteresis loop at high pressures.

A significant contribution to the specific surface area and total pore volume was produced by micropores with a size of $0.5-2 \mathrm{~nm}$ was determined by distribution of pore volume and area by size. Furthermore, mesoporous $2-6 \mathrm{~nm}$ in size are formed a porous volume of $0.28 \mathrm{~cm}^{3} / \mathrm{g}[10]$.

The quantitative characteristics of the porous structure of AC are presented in Table 1.

The obtained AC material is microporous with mesopores, which make up to $15 \%$ of the total surface area. The surface area is equal to $1236 \mathrm{~m}^{2} / \mathrm{g}$, determined by three methods, correlates within the error, is $10 \%$. 
Table 1

Sorption characteristics of AC

\begin{tabular}{|c|c|c|c|c|c|c|c|c|}
\hline Sample & $\begin{array}{l}S_{\mathrm{BET}}, \\
\mathrm{m}^{2} / \mathrm{g}\end{array}$ & $\begin{array}{c}S_{L}, \\
\mathrm{~m}^{2} / \mathrm{g}\end{array}$ & $\begin{array}{l}S_{D F T}, \\
\mathrm{~m}^{2} / \mathrm{g}\end{array}$ & $\begin{array}{c}S_{t \text {-micro }}, \\
\mathrm{m}^{2} / \mathrm{g}\end{array}$ & $\begin{array}{c}S_{B J H-\text { meso }} \\
\mathrm{m}^{2} / \mathrm{g}\end{array}$ & $\begin{array}{c}S_{\text {micro }} \\
\%\end{array}$ & $\begin{array}{l}V_{\text {total }}, \\
\mathrm{cm}^{3} / \mathrm{g}\end{array}$ & $\begin{array}{l}V_{\text {micro, }} \\
\mathrm{cm}^{3} / \mathrm{g}\end{array}$ \\
\hline $\mathrm{AC}$ & 1236 & 1405 & 1085 & 1040 & 160 & 84 & 0.69 & 0.41 \\
\hline
\end{tabular}
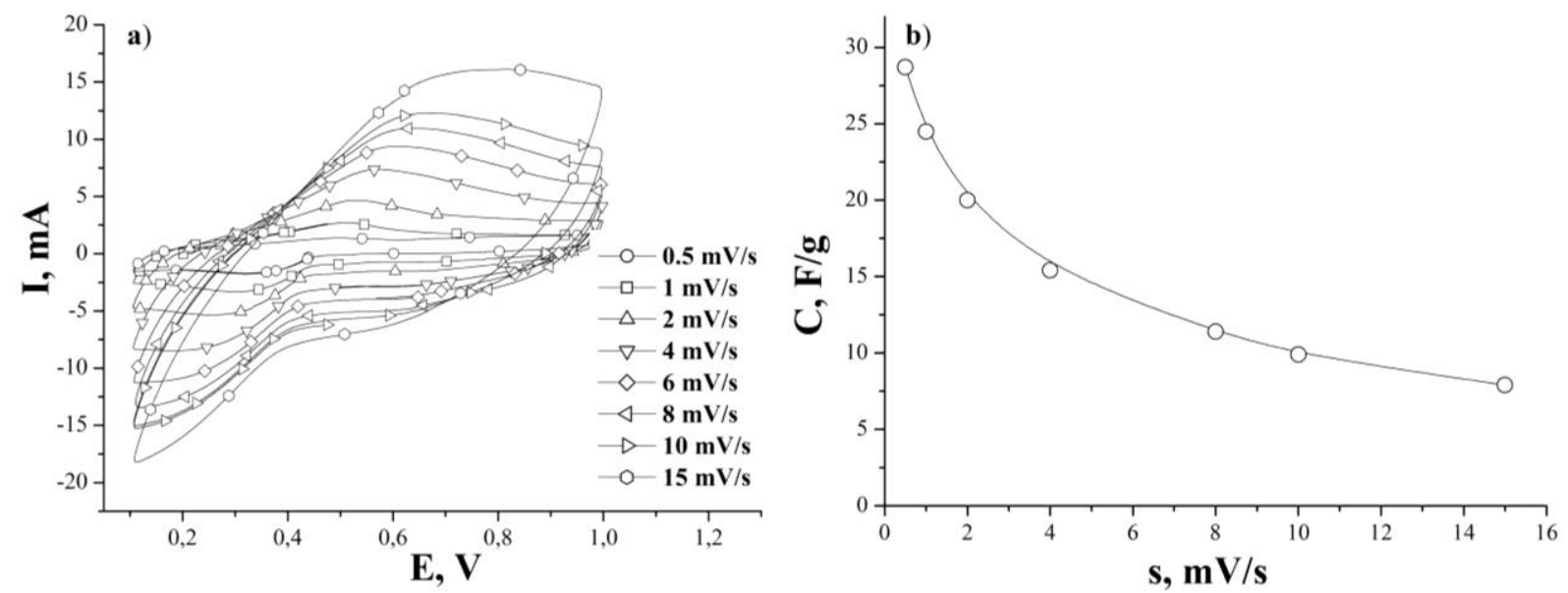

Fig. 2. Potentiodynamic curves were obtained for the $\alpha-\mathrm{MnO}_{2} /$ electrolyte system at scan rates from 1 to $15 \mathrm{mV} / \mathrm{s}$ a) and the dependence of the specific capacity of the system on the scan rates b).
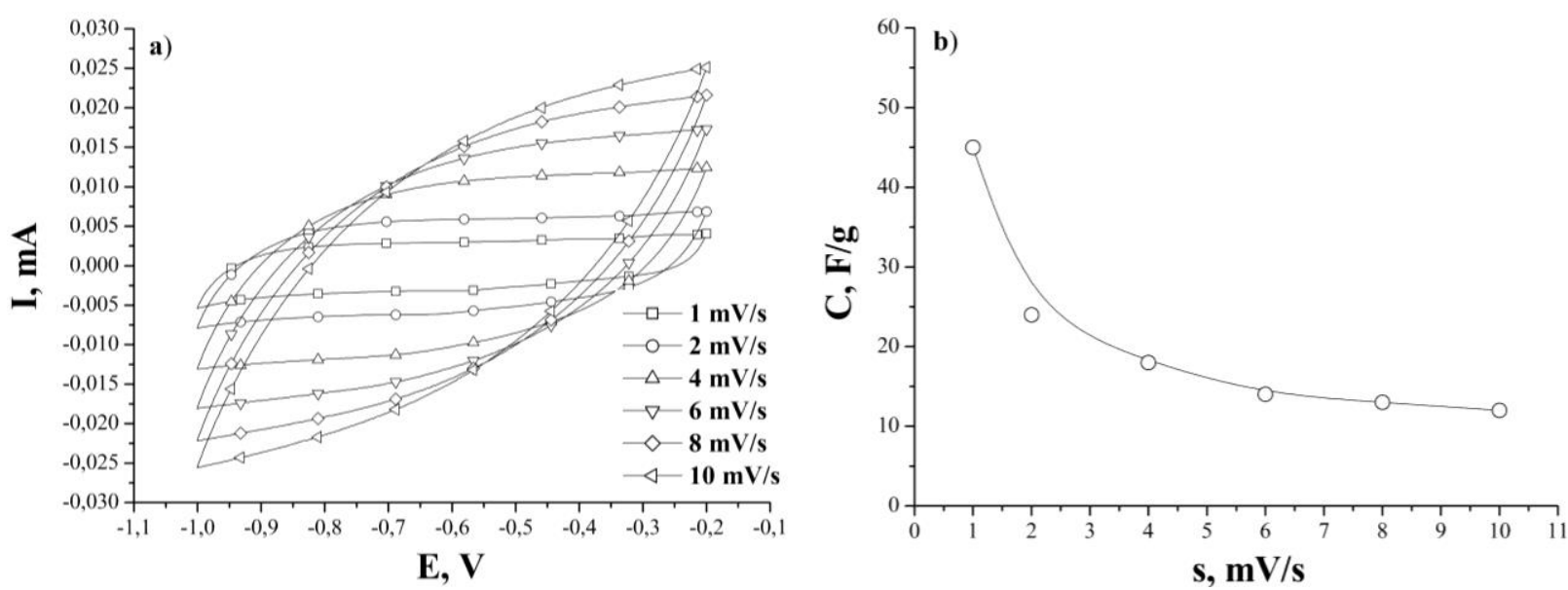

Fig. 3. Potentiodynamic curves obtained for the system AC/electrolyte a) and the dependence of the specific capacity of the system on the scan rates.

The micropore volume determined by the t-method is set to $0.41 \mathrm{~cm}^{3} / \mathrm{g}$, which is about $60 \%$ of the total pore volume determined at the maximum pressure. Mesopores play the role of transport channels for adsorbate or electrolyte to enter micropores.

\section{Electrochemical parameters of symmetric and asymmetric supercapacitors}

It was determined that the cyclic voltammetry curves obtained for the $\alpha-\mathrm{MnO}_{2} /$ electrolyte system are asymmetric over the entire range of scan rates by the method of cyclic voltammetry (CV) (Fig. 2a).

The CV curves show that redox peaks are at both the anodic $(\mathrm{U}=0.5 \mathrm{~V})$ and cathodic $(\mathrm{U}=0.4 \mathrm{~V})$ curves, respectively, which shift towards a lower potential with increasing scan rate. Moreover, it is evidence of the passage of electrochemical reactions of charge accumulation due to reverse transitions of $\mathrm{Mn}^{3+}$ to $\mathrm{Mn}^{4+}$

Figure $2 \mathrm{~b}$ shows the dependence of the specific capacity of the $\alpha-\mathrm{MnO}_{2} /$ electrolyte system on the rate of change in the applied potential.

An increase in the scan rates (from $5 \mathrm{mV} / \mathrm{s}$ to $15 \mathrm{mV} / \mathrm{s}$ ) leads to a slight decrease in the specific capacity of the system, which indicates the prospect of using these materials at high scan rates.

It was determined that after 5, 50 and 150 scan cycles, the $\mathrm{CV}$ curves retain their usual shape, this shape is indicates the reversibility of charge-discharge processes occurring in a system with electrodes based on $\alpha-\mathrm{MnO}_{2}$ in $\mathrm{Li}_{2} \mathrm{SO}_{4}$ electrolyte.

The CV curves of the AC/electrolyte system are typical for EC with EDL (Fig. 3, a). With an increase in the scan rate from 1 to $10 \mathrm{mV} / \mathrm{s}$, the potentiodynamic curves deviate from a rectangular shape due to an increase in the 


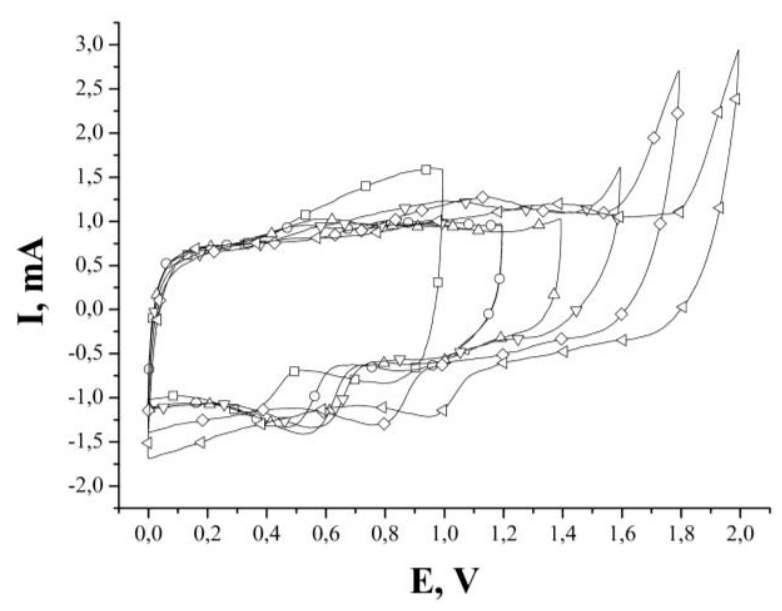

Fig. 4. Potentiodynamic curves of the $\mathrm{AC} / \mathrm{Li}_{2} \mathrm{SO}_{4} /$ $\alpha-\mathrm{MnO}_{2}$ system at a scan rate of $1 \mathrm{mV} / \mathrm{s}$.

internal resistance of the system.

The shape of the obtained CV curves is typical for EC with carbon electrodes in aqueous electrolytes [11]. At low scan rate, the $\mathrm{CV}$ curves have a symmetric approximate rectangular shape and, which is typical, there are no peaks that are responsible for the course of redox processes in the system. The maximum value of the specific capacity (Fig. $2, \mathrm{~b}$ ) of a carbon electrode in $\mathrm{Li}_{2} \mathrm{SO}_{4}$ electrolyte is $45 \mathrm{~F} / \mathrm{g}$.

Figures 2, b and 3, b shows the dependences of the specific capacity on the scan rate for systems based on $\mathrm{AC}$ and $\alpha-\mathrm{MnO}_{2}$ respectively. Furthermore, with an increase in the scan rate from $1 \mathrm{mV} / \mathrm{s}$ to $15 \mathrm{mV} / \mathrm{s}$, the specific capacitance for both systems decreases monotonically. Thus, it is can be noted that the change in the specific capacitance from the scan rate for both systems is practically the same, which is positive during the systems works.

A hybrid electrochemical system of the $\mathrm{AC} / \mathrm{Li}_{2} \mathrm{SO}_{4} /$ $\alpha-\mathrm{MnO}_{2}$ type was formed based on carbon material and manganese oxide of the $\alpha$ form in the negative and positive potential range respectively. It is possible to an increase in the energy characteristics of an electrochemical cell due to the use of materials with a different nature of charge accumulation in the electrochemical system, which allows it to function at

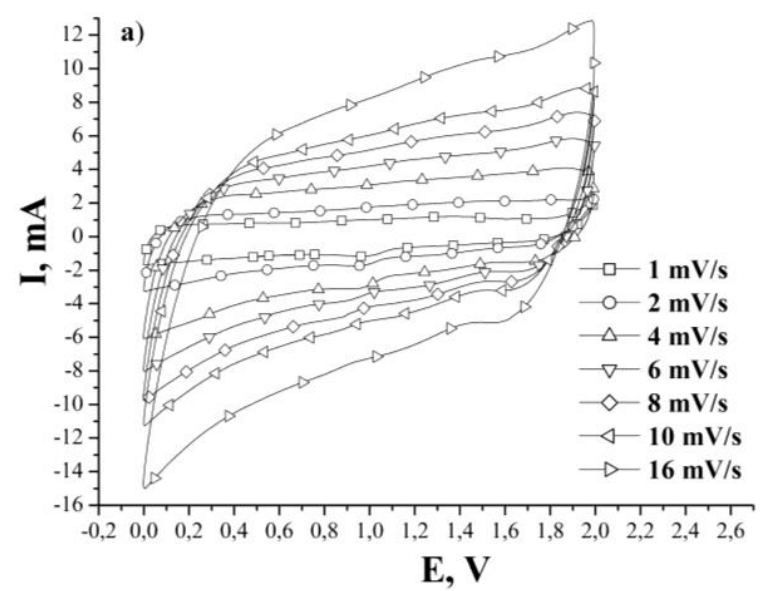

higher voltages. The research of the combination functioning of electrode materials in a hybrid electrochemical system was carried out by the potentiodynamic method. In order to determine the optimal operating voltage of a single element, potentiodynamic research were carried out with a gradual increase in the maximum voltage (step $0.2 \mathrm{~V}$ ) in the range from 1.0 to $2.0 \mathrm{~V}$ (Fig. 4). In the entire voltage range, the operation of the electrochemical system was stable. Therefore, further electrochemical research were carried out in this potential range.

The CV curves (Fig. 5,a) are characterized by the presence of redox peaks, which are responsible for the redox reactions, mainly according to the scheme $\mathrm{Mn}^{3+} \underset{\text { discharge }}{\stackrel{\text { charge }}{\rightleftarrows}} \mathrm{Mn}^{4+}$.

The dependence of the specific capacity of HEC on the cycle rate was determined based on experimentally obtained potentiodynamic curves (Fig. 5a,b). The maximum value of the specific capacitance is $46.5 \mathrm{~F} / \mathrm{g}$. The HEC model has shown stability in the voltage range from 0 to 2 for more than 500 cycles.

The total capacity of the HEC can be divided into the capacity of the electric double layer $\left(C_{E D L}\right)$ and the diffusion-controlled redox capacity due to Faraday's fast reverse reactions $\left(C_{F}\right) C=C_{E D L}+C_{F}$, based on the data obtained with (Fig. 5, b) [12].

In the kinetic model [13], it is assumed that the scan rate affects the total specific electrochemical capacity of the system, since the diffuse component of the capacity $\left(C_{F}\right)$ is a function of the reaction time. Thus, the scan rate can be considered inverse to the diffusion time. Furthermore, in the case of semi-infinite linear diffusion, the total capacity is related to the scan rate by the following equation $C=C_{s=\infty}+a / \sqrt{s}$ where $a$ is constant value, and $C_{E D L}=C_{S=\infty}$.

A decrease in the scan rate leads to an increase in the specific capacity (Fig. 6,b). Thus, the dependence of the specific capacity on the scan rate can be extrapolated in the other direction to $s=0$ using the functional dependence on s [13]. Since $C$ increases linearly with $s^{-1 / 2}$, then $1 / C$ should decrease linearly with $s^{1 / 2}$. Then,

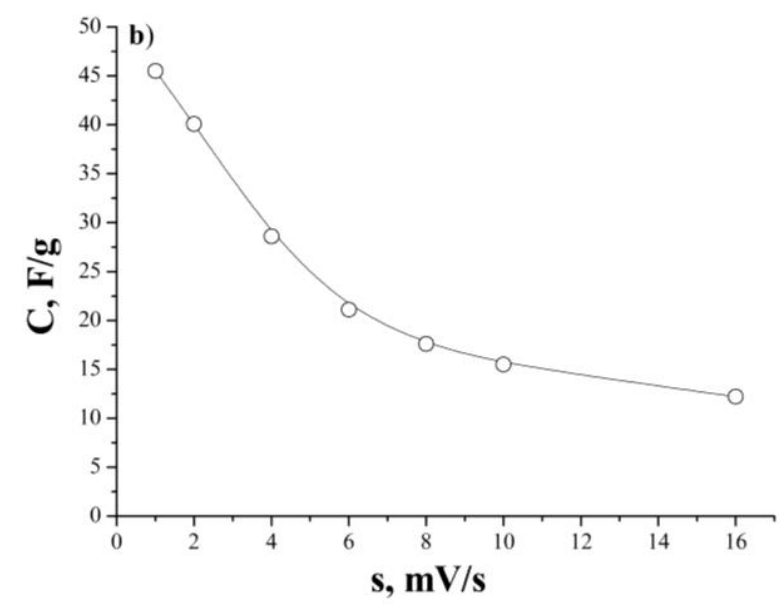

Fig. 5. Potentiodynamic curves of the $\mathrm{AC} / \mathrm{Li}_{2} \mathrm{SO}_{4} / \alpha-\mathrm{MnO}_{2}$ system in the voltage range from 0 to $2.0 \mathrm{~V}$ at scan rates of from 1 to $16 \mathrm{mV} / \mathrm{s}$ a) and the dependence of the specific capacity of the system on the scan rate b). 

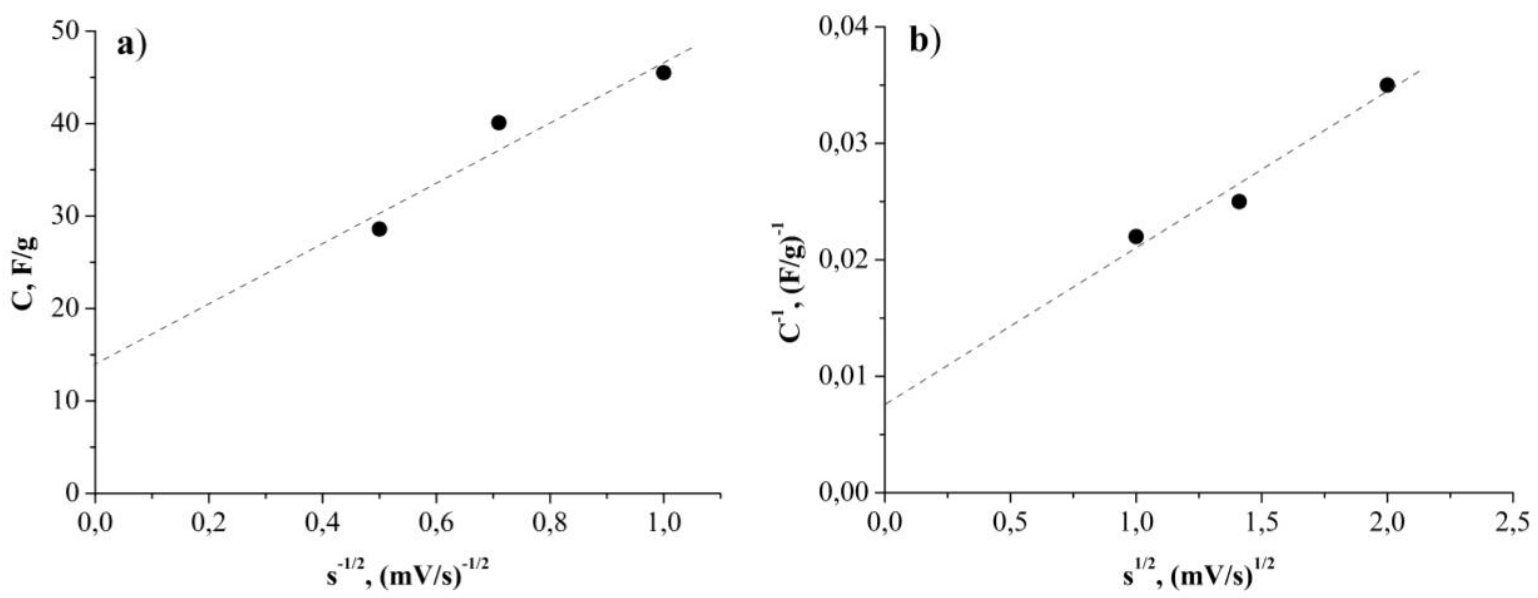

Fig 6. Dependence of $C$ on $s^{-1 / 2}$ a) and $1 / C$ on $s^{1 / 2}$ b) for $\mathrm{HEC}$ in $\mathrm{Li}_{2} \mathrm{SO}_{4}$ electrolyte.
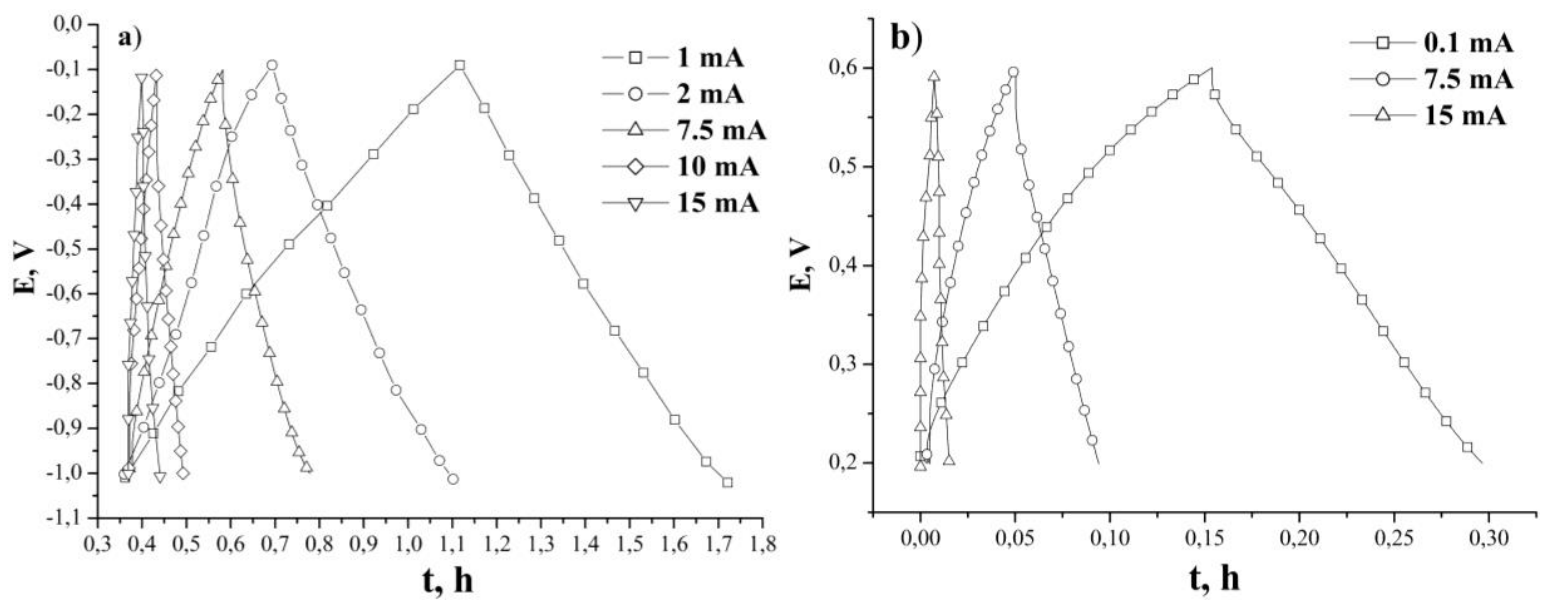

Fig. 7. Charge / discharge curves for the AC/electrolyte system a) and $\alpha-\mathrm{MnO}_{2}$ / electrolyte b).

$1 / c=1 c_{c_{n-0}}=b \sqrt{s}$ where $C_{s=0}$ is the maximum specific capacity that can be obtained, $b$ is a constant. Extrapolation of the $C$ dependences from $s^{-1 / 2}$ to the $Y$-axis (Fig. 6,a) made it possible to determine the specific capacity of the EDL of the materials under research (Table 2).

Table 2

\begin{tabular}{|c|c|}
\hline $\mathrm{C}_{\mathrm{DEL}}, \mathrm{F} / \mathrm{g}$ & 13.85 \\
\hline $\mathrm{C}_{\max }, \mathrm{F} / \mathrm{g}$ & 125 \\
\hline $\mathrm{C}_{\mathrm{DEL}} / \mathrm{C}_{\max }$ & 0.11 \\
\hline
\end{tabular}

The discharge curves of the research electrochemical systems are shown in Fig. 7. For the AC/electrolyte electrochemical system in the negative potential range (Fig. 7, a), there is a linear dependence of voltage on time, at constant current, which indicates electrostatic charge accumulation.

For the $\alpha-\mathrm{MnO}_{2}$ /electrolyte electrochemical system in the positive potential range, at low currents (Fig. 7, b), the slope of the discharge curve changes, which is due to the simultaneous implementation of two mechanisms of energy accumulation namely the formation of EDL by electrolyte ions on the surface of the electrode material and the occurrence of Faraday accumulation reactions charge.

The use of materials with different nature of charge accumulation and in different potential ranges made it possible to design a hybrid electrochemical system operating at a maximum voltage of $2 \mathrm{~V}$ in an aqueous electrolyte (Fig. 8,a).

At low operating currents on the discharge curves (Fig. 8,a), there is practically no voltage drop during discharge, which indicates the minimum internal resistance of the designed electrochemical system. The system under research is electrochemically stable in this voltage range, as evidenced by the constant value of the Coulomb efficiency over more than 500 operating cycles. The specific energy characteristics of the systems under research (Fig. 8,b) were determined, namely, the dependence of the specific energy on the discharge current based on the obtained discharge curves (Fig. 7 and Fig. 8, a). The maximum values of the specific energy for the systems $\alpha-\mathrm{MnO}_{2}$ /electrolyte, $\mathrm{AC} /$ electrolyte, and HEC with electrodes based on $\mathrm{AC} /$ $\mathrm{Li}_{2} \mathrm{SO}_{4} / \alpha-\mathrm{MnO}_{2}$ are 39.4, 73.9 and $87.7 \mathrm{~J} / \mathrm{g}$, respectively. 

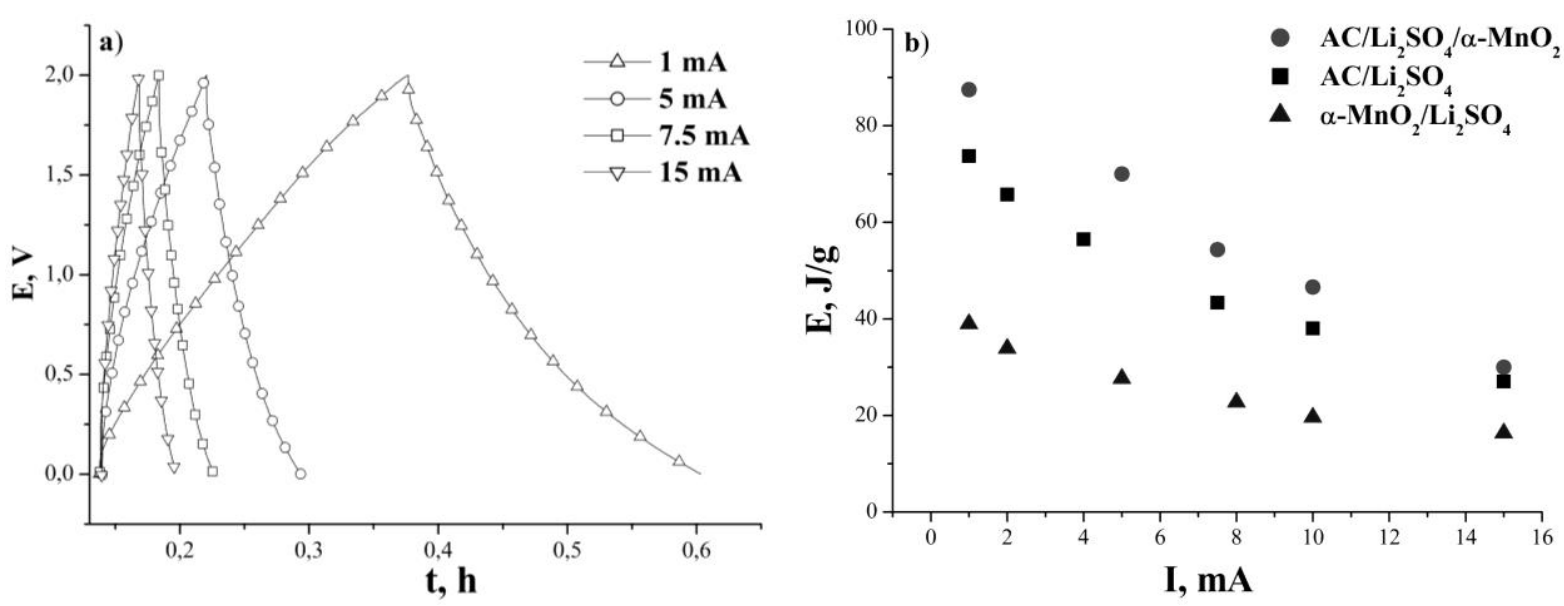

Fig. 8. Charge / discharge curves for $\mathrm{HEC} \mathrm{AC} / \mathrm{Li}_{2} \mathrm{SO}_{4} / \alpha-\mathrm{MnO}_{2}$ a) and the dependence of the specific energy on the discharge current $\mathrm{b}$ ).

\section{Conclusion}

It was determined that the obtained results of the hybrid supercapacitor with electrodes based on $\mathrm{AC}$ and $\alpha-\mathrm{MnO}_{2}$ in $\mathrm{Li}_{2} \mathrm{SO}_{4}$ is characterized by better energyefficient parameters than symmetric supercapacitors based on two carbon electrodes, probably due to the following structural features of electrode materials.

On the one hand, the porous structure of carbon guarantees a high specific surface area $\left(1236 \mathrm{~m}^{2} \mathrm{~g}^{-1}\right)$ with an average pore size of $2-6 \mathrm{~nm}$. On the other hand, the channel structure of the $\alpha-\mathrm{MnO}_{2}$ transition material with a particle size of 12 - 16 nanometers provides fast ionic and electronic mechanisms of charge transfer, as well as the course of the redox reaction and cyclic processes, and, consequently, leads to an increase in the specific capacity of the electrochemical system.
Kolkovskyi P.I. - Doctoral student of the Department of Material Science and New Technology;

Ostafiychuk B.K. - Doctor of Sciences, Professor, Head of the Department of Material Science and New Technology;

Kolkovskyi M.I. - PhD student, of the Department of Material Science and New Technology;

Ivanichok N.Ya - PhD, senior specialist of the Department of Material Science and New Technology;

Sklepova S-V.S. - senior laboratory assistant of the Department of Materials Science and New Technologiesж

Rachiy B.I.- doctor of physical and mathematical sciences, Professor of the Department of Materials Science and Advanced Technologies.

[1] B.E. Conway, Electrochemical Supercapacitors: Scientific Fundamentals and Technological Applications (N.Y. Kluwer Academic Plenum Publishers, 1999).

[2] B.K. Ostafiychuk, R.P. Lisovskiy, A.H.Z. Al-Saedi, B.I. Rachiy, V.O. Kotsyubynsky, P.I. Kolkovsky, R.I. Merena, A.B. Hrubiak, Journal of Nano- and Electronic Physics 11(3), 03036 (2019) (doi: 10.21272/jnep.11(3).03036).

[3] R. Lisovsky, B. Ostafiychuk, I. Budzulyak, V. Kotsyubynsky, A. Boychuk, B. Rachiy, Acta Physica Polonica A. 133(4), 876 (2018) (doi: 10.12693/APhysPolA.133.876).

[4] B. Conway, W. Pell, Proceedings of the 12-th International Seminar on DLC and Similar Energy Storage Devices (Deerfield Beach, Florida, USA, 2002).

[5] A.I. Belyakov, The 6-th International Similar on DLC and Seminar Energy Storage Devices ( Deerfield Beach, Florida, USA, 1996).

[6] J. Miller, P. Simon, Science 321(5889), 651 (2008) (doi: 10.1126/science. 1158736).

[7] L. Zhang, X. Zhao, Chemical Society Reviews 38(9), 2520 (2009) (doi: 10.1039/B813846J).

[8] J. Miller, P. Simon, Science 321(5889), 651 (2008) (doi: 10.1126/science.1158736).

[9] L. Zhang, X. Zhao, Chemical Society Reviews 38(9), 2520 (2009) (doi: 10.1039/B813846J).

[10] P.I. Kolkovskyi, B.I. Rachiy, M.I. Kolkovskyi, B.K. Ostafiychuk, I.P. Yaremiy, V.O. Kotsyubynsky, \& R.V. Ilnitsky, Synthesis and Electrochemical Properties of Mesoporous $\alpha-\mathrm{MnO} 2$ for Supercapacitor Applications, Journal of nano and electronic physics 12(3), 03030 (2020) (doi: 10.21272/jnep.12(3).03030).

[11] B.K. Ostafiychuk, M.I. Kolkovskyi, B.I. Rachiy, P. I. Kolkovskyi, N.Y. Ivanichok, \& R.V. Ilnitsky, Physics and Chemistry of Solid State, 21(1), 27 (2020) (doi: 10.15330/pcss.21.1.27-34

[12] B.I. Rachiy, I.M. Budzulyak, V.M. Vashchynsky, N.Y. Ivanichok, M.O. Nykoliuk, Nanoscale Research Letters 11(1), art. no. 18, 1 (2016), 
[13] H. Wang, L. Pilon, Electrochimica Acta 64, 130 (2012).

[14] S. Ardizzone, G. Fregonara, \& S. Trasatti, Electrochimica Acta 35, 263 (1990).

П.І. Колковський, Б.К. Остафійчук, М.І. Колковський, Н.Я. Іванічок,

С.С. Склепова, Б.І. Рачій

\section{Механізми накопичення заряду в електрохімічних системах, сформованих на основі нанопористого вуглецю та оксиду мангану}

ДВНЗ “Прикарпатський національний університет імені Василя Стефаника”, Івано-Франківськ, Украӥна, Pkolkovskyy@gmail.com

В даній роботі проаналізовано процеси, що відбуваються в електрохімічних системах на основі нанопористого вуглецевого матеріалу та оксиду мангану у водному розчині сульфату літію, а також показано доцільність сумісного функціонування даних матеріалів, як електродів гібридного електрохімічного конденсатора. Поєднання електродних матеріалів з різними механізмами накопичення заряду: формування подвійного електричного шару на вуглеці та протікання редокс реакцій на манган оксиді призвело до зростання накопиченої енергії більш ніж на $25 \%$. Сформований макет гібридного електрохімічного конденсатора на основі водного електроліту $є$ електрохімічно стабільним при робочій напрузі 2 В.

Ключові слова: нанопористий вуглецевий матеріал, Манган оксид, гібридні електрохімічні конденсатори, сульфат літію, вольтамперометрія. 